\title{
TABANID SPIROPLASMAS FROM FRANCE: CHARACTERIZATION, ECOLOGY AND EXPERIMENTAL STUDY
}

\author{
F. LE GOFF*, M. MARJOLET***, I. HUMPHERY-SMITH*1, M. LECLERCQ**, \\ C. HELIAS*, F. SUPPLISSON***, C. CHASTEL*
}

\begin{abstract}
SUMMARY
During 1989 and 1990, tabanid flies were collected from two different areas in Western France and assayed for spiroplasmas. From Central Britanny 62 flies of 9 different species yielded 20 spiroplasma isolates belonging to 6 different serogroups: VIII, XIV, XXIII, HYOS, TABS 1, TAAS. From Atlantic biotopes 81 flies of three different species yielded 58 isolates belonging mainly to serogroup IV, but also TABS 1, HYOS and XIV. All the 78 French isolates were able to multiply in vitro at $37^{\circ} \mathrm{C}$.

Of 240 flower or plant specimens tested from " Brière » none yielded spiroplasmas.
\end{abstract}

81 animal sera from « Brière » were also examined. Using the Deformation test and 11 different spiroplasmas from honey bees, mosquitoes and tabanids, $61 / 76$ bovine sera (or $80,3 \%$ ) were found to be positive but exclusively for the spiroplasma Ar 1357, a mosquito spiroplasma belonging to serogroup $\mathrm{XVI}_{3}$ and previously isolated in France from Aedes mosquitoes.

At present we have no explanation for the paradoxical absence of antibody to tabanid spiroplasmas in cattle since all French tabanid spiroplasmas are able to multiply in vitro at $37^{\circ} \mathrm{C}$ and, at least for three isolates, in suckling mice.

RÉSUMÉ : Spiroplasmes de Tabanidae en France : caractérisation, écologie et étude expérimentale.

En 1989 et 1990, des taons ont été récoltés dans deux endroits différents de l'Ouest de la France et examinés pour la présence de spiroplasmes. Du Centre de la Bretagne, 62 taons appartenant à 9 espèces différentes ont permis d'isoler 20 spiroplasmes appartenant à 6 sérogroupes différents: VIII, XIV, XXIII, HYOS, TABS 1, TAAS. A partir de biotopes atlantiques, 81 taons appartenant à 3 espèces différentes ont fourni 58 isolements de spiroplasmas appartenant essentiellement au sérogroupe IV, mais aussi TABS 1, HYOS et XIV. Toutes les souches isolées en France sont capables de se multiplier à $37^{\circ} \mathrm{C}$.
Sur 240 spécimens de végétaux récoltés dans le parc de Brière aucun n'a fourni d'isolement. 81 sérums animaux de même origine ont été examinés vis-à-vis de spiroplasmes d'abeilles, de moustiques et de taons. 61 sérums bovins sur $76(80,3 \%)$ ont été trouvés positifs par le test de déformation, mais exclusivement pour le spiroplasme de moustique Ar 1357 (sérogroup $\mathrm{XVI}_{3}$ ) isolé d'Aedes en France.

Nous n'avons pas d'explication pour l'absence d'anticorps visà-vis des spiroplasmes de Tabanidae chez les animaux, car toutes les souches isolées en France se multiplient à $37^{\circ} \mathrm{C}$ in vitro, et trois d'entre elles le font également chez le souriceau.

\section{INTRODUCTION}

Spiroplasmas (Mollicutes: Spiroplasmataceae) are motile procaryotes lacking a cell-wall and exhibiting a helical morphology during their exponential growth phase. They are classified into 24 serological groups and occasionally subgroups, plus a number of putative groups under evaluation.

Spiroplasmas are currently known from plants, insects

* Laboratoire de Virologie, Faculté de Médecine, BP 815, F 29285 Brest Cedex.

** Faculté des Sciences Agronomique de l'État, B-5030 Gembloux, Belgique.

*** Laboratoire de Parasitologie et Pathologie exotique, Faculté de Médecine, 1, rue Gaston-Veil, F 44035 Nantes Cedex. Accepté le : 29 janvier 1993.

1. Present adress: Department of Microbiology, University of Sydney, Australia, 2006. and ticks. Depending upon the species or serotype, they behave as symbionts or true pathogens. For instance, Spiroplasma citri (group I-1) the prototype species of the genus Spiroplasma, is highly pathogenic for Citrus.

The isolation of spiroplasmas from haematophagous arthropods, such as ticks, mosquitoes and tabanids, raised considerable interest among pathologists concerning their eventual pathogenicity for domestic animals and man (Chastel and Humphery-Smith, 1991 ; Humphery-Smith et al., 1992). Other spiroplasmas appear as good condidates for the biological control of mosquitoes (Humphery-Smith et al., 1991a; 1991b; Worms-Le Morvan et al., 1991).

Recently a rich diversity of spiroplasmas has been isolated from Tabanidae in the USA (Clark et al., 1984; French et al., 1990; Whitcomb et al., 1990) and in France (Le Goff et al., 1991; Chastel et al., 1992). The present work completes our observations by adding new taxonomic, ecological and experimental data on tabanid spiroplasmas from France. 


\section{MATERIAL AND METHODS}

\section{STUDY AREAS}

During summer months of 1989 and 1990, deer flies and horse flies (Tabanidae) were collected from two different areas in Western France : 1) "Forêt de Paimpont " in Central Brittany and 2) " Parc Régional de la Brière » near the Loire River estuarine (Fig. 1). In the first area, flies were caught by methods previously described (Le Goff et al., 1991) whereas in the second collections were carried out using hand-nets, Mannitoba traps or, more simply, by collecting flies attracted to an open van.

\section{Methods of ISOlATION AND CHARACTERIZATION}

These have been previously detailed by le Goff et al. (1991). For serological characterization of tabanid isolates we used a number of antisera either prepared in our Laboratory or kindly supplied by $D^{r}$ J. G. Tully, National Institute of Allergy and Infectious Diseases, Frederick, Maryland, USA.

\section{MULTIPLICATIONS OF ISOLATES AT DIFFERENTS TEMPERATURES}

Three series of $\log 10$ dilutions in SP4 medium of each triplecloned isolate were incubated for 3 weeks respectively at $37^{\circ} \mathrm{C}$, $30^{\circ} \mathrm{C}$ and $20^{\circ} \mathrm{C}$. Color change in inoculated medium was recorded daily for each series and the specificity of the acidification controlled by dark field illumination. Results were expressed in Color Change Unit per milliliter $(\mathrm{CCU} / \mathrm{ml})$.

PATHOGenicity of isolates IN THE SUCKLING MOUSE MODEL

The isolates previously adapted to multiply at $37^{\circ} \mathrm{C}$ in vitro were assayed for multiplication and persistence in vivo, using a recently described suckling mouse model (Chastel et al., 1992).

\section{ATTEMPS OF ISOLATION FROM PLANTS AND FLOWERS}

240 specimens collected in area 2 during June 1990 were processed, as previously described (Chastel et al., 1990).

\section{SEROSURVEYS}

81 animal sera were collected from area 2 between March and November 1990 (3 horses, 2 sheep and 78 cattle). They were examined using the Deformation test (DT) (Williamson et al., 1978) and 11 different spiroplasmas from honey bees, mosquitoes and tabanids (groups I-2, IV, VIII, XIII, XIV, XVI, XXII, XXIII, HYOS, TABS 1 and TAAS).

\section{RESULTS}

ISOLATION AND CHARACTERIZATION OF TABANID SPIROPLASMES FROM FRANCE

A total of 78 spiroplasma isolates belonging to seven serogroups were isolated from the two study areas. In Central Britany (July, 1989), two species of deer fly and seven species of horse fly (62 specimens) yielded 20 isolates (Table I). Among these, Tabanus sudeticus proved to be the most hospitable, harbouring strains from serogroups XVI, XXIII and TABS 1.

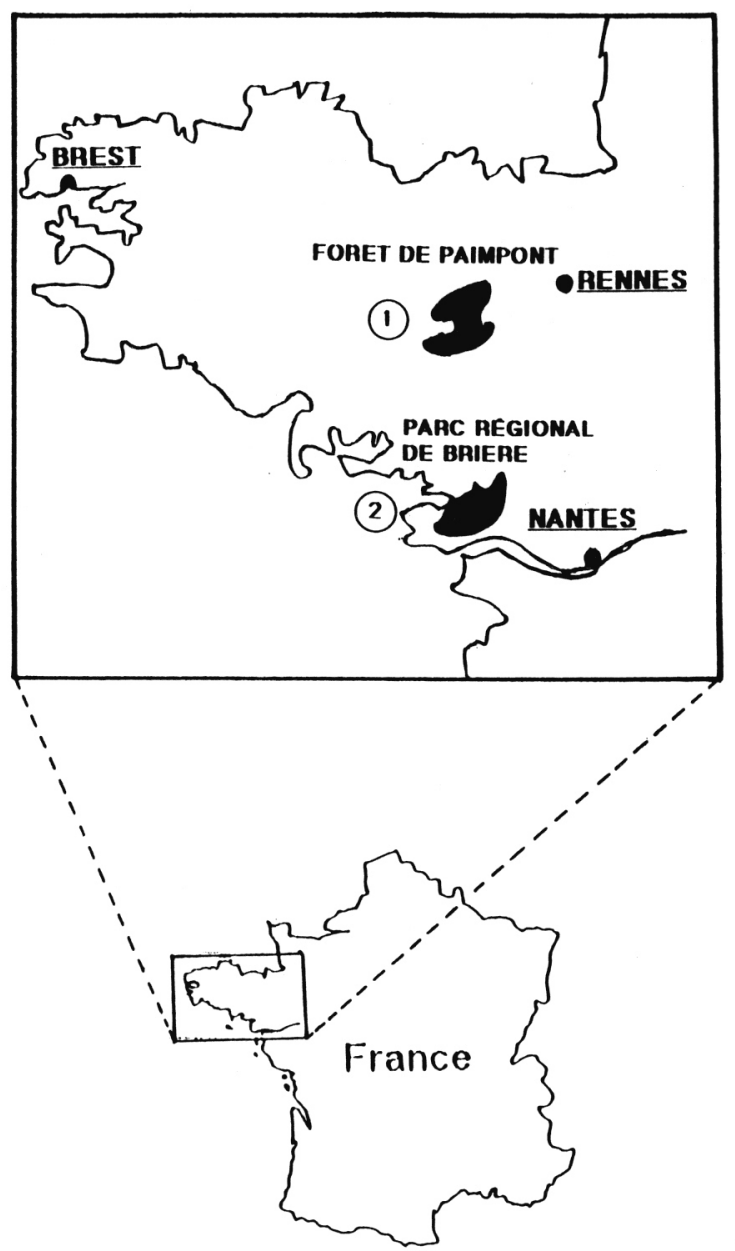

Fig. 1. - The two study areas in western France.

In « Brière » (June 1989 and June 1990), one species of deer fly and two species of horse fly ( 82 specimens) yielded a total of 58 isolates (Table II). Here, Hybromitra tropica produced 32 isolates ( 31 from serogroup IV) from 39 flies tested, while Chryrops pictus was host to five different spiroplasma serogroups and a non-helical mollicute, probably Mesoplasma seiffertii.

\section{CAPACITY OF ISOlATES TO MULTIPLY AT $37^{\circ} \mathrm{C}$ in vitro}

All the 78 French isolates were able to multiply in liquid SP4 medium at $37^{\circ} \mathrm{C}$ sometimes reaching titers as high as $10^{6}$ to $10^{10} \mathrm{CCU} / \mathrm{ml}$.

\section{CAPACITY OF ISOlates TO MULTIPLy AND PERSIST IN INOCULATED SUCKLING MICE}

Thirteen spiroplasma isolates belonging to seven different spiroplasma serogroups (IV, VIII, XIV, XXIII, TABS 1, TAAS, HYOS) and the non-helical mollicute were assayed in the suckling mouse model. 
TABLE I. - Spiroplasmas isolated from Central Britanny. Spiroplasma serogroup *:

\begin{tabular}{|c|c|c|c|c|c|c|c|c|}
\hline $\begin{array}{l}\text { Tabanid } \\
\text { species }\end{array}$ & $\begin{array}{l}\text { Number } \\
\text { of tested } \\
\text { flies }\end{array}$ & VIII & XIV & XXIII & HYOS & TABS & TAAS & Total \\
\hline $\begin{array}{l}\text { Tabanus } \\
\text { bromius }\end{array}$ & 26 & & 5 & & & & 1 & 6 \\
\hline T. bovinus & 5 & & 2 & & & & & 2 \\
\hline $\begin{array}{l}\text { T. sudeti- } \\
\text { cus }\end{array}$ & 13 & & 3 & 3 & & 2 & & 8 \\
\hline $\begin{array}{l}\text { Hybomitra } \\
\text { bimaculata }\end{array}$ & 2 & & 1 & & & & & 1 \\
\hline $\begin{array}{l}\text { H. distin- } \\
\text { guenda }\end{array}$ & 3 & & & & & & & 0 \\
\hline $\begin{array}{l}\text { Heptatoma } \\
\text { pellucens }\end{array}$ & 1 & 1 & & & & & & 1 \\
\hline H. pluvalis & 6 & & & & & & & 0 \\
\hline $\begin{array}{l}\text { Chrysops } \\
\text { pictus } \\
(=C . \text { vidua- } \\
\text { tus })\end{array}$ & 4 & & 1 & & & & & 1 \\
\hline $\begin{array}{l}\text { C. caecu- } \\
\text { tiens }\end{array}$ & 2 & & & & 1 & & & 1 \\
\hline Total & 62 & 1 & 12 & 3 & 1 & 2 & 1 & 20 \\
\hline
\end{tabular}

TABLE II. - Spiroplasmas isolated from « Brière ». Spiroplasma serogroup *:

\begin{tabular}{|c|c|c|c|c|c|c|c|}
\hline $\begin{array}{l}\text { Tabanid } \\
\text { species }\end{array}$ & $\begin{array}{c}\text { Number } \\
\text { of tested } \\
\text { flies }\end{array}$ & IV & VIII & XIV & HYOS & TABS & Total \\
\hline $\begin{array}{c}\text { Hybromitra } \\
\text { tropica }\end{array}$ & 39 & 31 & & & & 1 & 32 \\
\hline $\begin{array}{c}\text { H. pluvialis } \\
\text { Chrysops } \\
\text { pictus } \\
(=C \text {. vidua- } \\
\text { tus })\end{array}$ & $\begin{array}{r}1 \\
41\end{array}$ & 13 & 4 & 1 & 3 & $\begin{array}{l}1 \\
4\end{array}$ & $\begin{array}{r}1 \\
25\end{array}$ \\
\hline Total & 81 & 44 & 4 & 1 & 3 & 6 & 58 \\
\hline
\end{tabular}

* No isolate belonging to groups I-2, XIII, XVII, XVIII, XXII, XXIII and TAUS.

Only three isolates were able to both multiply and persist in the brain of suckling mice inoculated by intracerebral (i.c.) route: strain HP 140 (group VIII) from $H$. pellucens, strain CP 42 (group VIII) from $C$. pictus, and strain TB 44 (group TAAS) from $T$. bromius. CP 42 and TB 44 underwent three passages in mice without loss of virulence but were lost during the fourth passage, an observation already made with the bee-pathogen, Spiroplasma melliferum (Chastel et al., 1991). However, HP140 underwent six passages during which its virulence for mice increased and led to neurological symptoms, brain lesions and death in some individuals (Chastel et al., 1992).

ATTEMPTS TO ISOLATE MOLLICUTES FROM PLANTS AND FLOWERS

None of the 240 specimens tested yielded mollicutes. This held true both for washing or crushed specimens.

Details of the flowers and plants collected during the survey in « Brière » (June 12, 1990) are: Carex stricta 10, Cladium mariscus 50, Convolvulus sepium 10, Hydrocotyle vulgaris 10, Iris pseudacorus 10, Juncus conglomeratus 10 , Lysimachia vulgaris 10, Nympha alba 20, Pencedanum palustre 10, Phalaris arundinacea 10, Phragmites communis 50, Salix atrocinerea 10, Scirpus lacustris 10, Scirpus palustris 10, Typha angustifolia 10.

\section{SEROSURVEY IN DOMESTIC ANIMALS}

No antibody to any spiroplasma was found in horse or sheep sera. On the contrary, 61/76 bovine sera ( $80 \%$ ), were found positive with DT titers ranging from 1:20 to 1:80. These sera reacted only with the Spiroplasma cantharicola antigen (mosquito-derived strain Ar 1357; group $\mathrm{XVI}_{3}$ ) and not with tabanid spiroplasma antigens.

\section{DISCUSSION}

« Tabanidae are considered to be among the major dipteran pests of man and animals worldwide » (Foil, 1989). They are able to transmit to animals and man a great number of pathogenic agents including viruses, bacteria, protoza and helminths (Krinsky, 1976). The study of any symbiont or potential pathogen encountered in these haematophagous diptera therefore deserves our attention.

Our preliminary studies in France, have already established a number of important facts:

Spiroplasmas are as prevalent among the tabanidae in France as in the USA. Their prevalence may be as hight as 31 from 39 flies $(79,5 \%)$ for group IV spiroplasmas in Hybomitra tropica. Tabanid spiroplasmas isolated from two different areas in Western France belong to serogroups already described from the USA. Even if antigenic difference can be shown between French and North American strains, no « new », ungrouped spiroplasma was isolated.

All the 78 French strains were able to multiply to high titers in vitro at $37^{\circ} \mathrm{C}$ (the corporeal temperature of mammals). This property makes them a priori able to infect homeothermic organisms such as domestic animals and man. However when thirteen of these strains were assayed by i.c. route in the suckling mouse model, only three were found able to infect mice. In addition, there is no correlation between the antigenic group of the tested strain (VIII 
or TAAS in the present case), and its pathogenicity for mice since other strains of the same groups were found to be non pathogenic.

Although the disease hypothesis was apparently not confirmed by the negative results of serosurveys carried out in Brière using tabanid spiroplasmas antigens, definitive conclusions could be made with caution. The same survey showed a very high prevalence of antibody to a group $\mathrm{XVI}_{3}$ spiroplasma ( $S$. cantharicola) isolated from Aedes mosquitoes in France (Chastel et al., 1987; Le Goff et al., 1990). Moreover, antibody to the same mosquito spiroplasma has been previously detected in cattle, in another area in France, Savoy (Chastel et al., 1987). Serosurveys in humans living in the same biotopes could be most interesting.

Another factor to be taken in account is that tabanid hosts which yielded pathogenic spiroplasmas do bite domestic animals and or man. $H$. pellucens is a cattle pest and has not been observed biting humans, while $C$. pictus (=C. viduatus) rarely bites man an $T$. bromius frequently does. In addition, $T$. bromius is a larger species than the two others thus inducing more frequently defense reactions from the host.

Spiroplasma disease, if it is produced in man or animals, must be rare and exotic as large scale epidemics due to an unknown infectious agent are not in evidence. Such disease is obviously not proportional to the high prevalence of spiroplasmas in some tabanid species or to the sometimes elevated biting rates of tabanids. Thus although potential for disease undoubtly exists, on must try to find an explanation for its absence or reduced incidence. Factors likely to play a role include the blood brain barrier of vertebrates or the compartmentisation of spiroplasmas to certain organ systems within the tabanid not likely to be implicated in transmission. The former might explain the negative results obtained during the serosurvey of domestic animals in « Brière ». The absence of antibody production (DT) in rodents experimentally infected by spiroplasmas (Chastel et al., 1992) must also be taken in account.

Nonetheless, transmission to animals or man of tabanid spiroplasmas pathogenic for mice may be favoured due to the painful nature of tabanid bites and the swatting reflex they induce in those bitten. Spiroplasmas libered from crushed tabanids could then feasilly penetrate in the injured skin (Chastel et al., 1992).

Acknowledgments. - This work was supported in part by grants from ANVAR (A $9012099 \mathrm{E}$ ), MRE (90 H 0123) and INSERM (CRE 91 0603), Paris, and Fondation Langlois, Rennes. The authors would like to express their thanks to Mme le $\mathrm{P}^{\mathrm{r}} \mathrm{G}$. ANDRÉFontaINE, Zoonoses-Maladies contagieuses, ENVN, F 44087 Nantes et M. J. Guilloteau, Entente Interdépartementale de Démoustication du Littoral Atlantique, F 44320 Frossay, for helping us in sera and tabanid collections.

\section{REFERENCES}

Chastel C., Devau B., Le Goff F., Simitzis-Le Flohic A. M., Gruffaz R., Kerdraon G., Gilot B. : Mosquito spiroplasmas from France and their ecology. Isr. J. Med. Sci., 1987, 23, 683-686.

Chastel C., Gilot B., Le Goff F., Devau B., Kerdraon G., Humphery-Smith I., Gruffaz R., Simitzis-Le Flohic A. M. : New developments in the ecology of mosquito spiroplasmas. $\mathrm{Abl}$. Bakt., 1990, Suppl. 20, 1455-1460.

Chastel C., Humphery-Smith I. : Mosquito spiroplasmas. Adv. Dis. Vector Res., 1991, 7, 149-206.

Chastel C., Le Goff F., Humphery-Smith I. : Multiplication and persistence of Spiroplasma melliferum strain A56 in experimentally infected suckling mice. Res. Microbiol., 1991, 142, 411-417.

Chastel C., Le Goff F., Humphery-Smith I. : Un spiroplasme de Tabanidae capable de se multiplier et de persister dans le système nerveux central de la souris. C. R. Acad. Sc. Paris, 1992, 315, Sér. III, 229-233.

Clark T. B., Peterson B. V., Whitcomb R. F., Henegar R. B., Hackett K. J., Tully J. G. : Spiroplasmas in the Tabanidae. Israel J. Med. Sciences, 1984, 20, 1002-1005.

Foil L. D. : Tabanids as vectors of disease agents. Parasitol. Today, 1989, 5, 88-96.

French F. E., Whitcomb R. F., Tully J. G., Hackett K. J., Clark E. A., Henegar R. B., Wagner A. G., Rose D. L. : Tabanid spiroplasmas of the Southeast USA: new groups, and correlation with host life history strategy. Zbl. Bakt., 1990, Suppl. 20, 919-921.

Humphery-Smith I., Grulet O., Le Goff F., Chastel C. : Spiroplasma (Mollicutes: Spiroplasmataceae) pathogenic for Aedes aegypti and Anopheles stephensi (Diptera: Culicidae). J. Med. Entomol., 1991 a, 28, 219-222.

Humphery-Smith I., Grulet O., Le Goff F., Robaux P., Chastel C. : Bases expérimentales pour l'utilisation de spiroplasmes de moustiques dans la lutte contre les grandes endémies tropicales transmises par des moustiques. Bull. Soc. Path. Ex., 1991 b, 84, 693-696.

Humphery-Smith I., Chastel C., Le Goff F. : Spiroplasmas and spongiform encephalopathies. Med. J. Australia, 1992, 156, 142.

Krinsky W. L. : Animal disease agents transmitted by horse flies and deer flies (Diptera: Tabanidae). J. Med. Entomol., 1976, 13, 225-275.

Le Goff F., Marjolet M., Guilloteau J., Humphery-Smith I., Chastel C. : Characterization and ecology of mosquito spiroplasmas from Atlantic biotopes in France. Ann. Parasitol. Hum. Comp., 1990, 65, 107-110.

Le Goff F., Humphery-Smith I., Leclercq M., Chastel C. : Spiroplasmas from European Tabanidae. Med. Veterin. Entomol., 1991, 5, 143-144.

Whitcomb R. F., Hackett K. J., Tully J. G., Clark E. A., French F. E., Henegar R. B., Rose D. L., Wagner A. G. : Tabanid spiroplasmas as a model for mollicute biogeography. Zbl. Bakt., 1990, Suppl. 20, 931-933.

Williamson D. L., Whitcomb R. F., Tully J. G. : The spiroplasma deformation test, a new serological method. Current Microbiol., 1978, 1, 203-207.

Worms-Le Morvan J., Vazeille-Falcoz M.-C., Rhodain F. : Infection expérimentale de moustiques Aedes albopictus par la souche de spiroplasmes isolée de Culex annulus à Taiwan. Bull. Soc. Path. Ex., 1991, 84, 15-24. 